Kinestetik : Jurnal Ilmiah Pendidikan Jasmani

https://ejournal.unib.ac.id/index.php/kinestetik/index

DOI : $10.33369 /$ jk.v5i3.16430

\title{
SELF-EFFICACY OF NORTH MALUKU ATHLETE STUDENTS AT THE NATIONAL STUDENT SPORTS WEEK (POMNAS) DKI JAKARTA
}

\author{
Syahril Adam ${ }^{1 *}$, Eva Faridah ${ }^{2}$ \\ ${ }^{1}$ Sport and Physical Education, STKIP Kie Raha, Ternate, Indonesia. \\ ${ }^{2}$ Physical Education, Sport, Health and Recreation, Faculty of Sport Science, Universitas Medan, \\ Medan, Indonesia.
}

\begin{tabular}{l} 
Article Info \\
\hline Article History : \\
Received : June 2021 \\
Revised : September 2021 \\
Accepted :September 2021 \\
Available online : September \\
2021
\end{tabular}

\section{Keywords:}

Self-efficacy, athlete students, POMNAS

\begin{abstract}
The purpose of this study is to reveal the self-efficacy of North Maluku athlete students at the National Student Sports Week (POMNAS) 2019 in DKI Jakarta. So far, there have been many quantitative research publications on self-efficacy, but the results obtained have not explored the psychological dynamics of athletes more deeply. Through this study, researchers found new more indepth facts related to athletes' self-efficacy. This study uses a qualitative approach. Data collection is done when the athletes have finished competing, with the hope that the data obtained is more accurate because they are still in competition atmosphere. The subjects in this study were North Maluku athlete students who participated in the 2019 POMNAS activities in DKI Jakarta. The results of this study indicate that North Maluku Athlete students have high self-efficacy, this is indicated by the athletes knowing the level of each series of training programs undertaken, being able to complete a series of given training programs, and having the ability to complete the entire series of training programs.
\end{abstract}

\begin{tabular}{ll}
\hline Corresponding address & : Sport and Physical Education, STKIP Kie \\
& Raha, Ternate, Indonesia \\
*Corresponding email & : syahril_adam@stkipkieraha.ac.id
\end{tabular}

ISSN 2685-6514 (Online)

ISSN 2477-331X (Print) 


\section{INTRODUCTION}

The National Student Sports Week (POMNAS) is a routine activity held every two years by the Directorate of Learning and Student Affairs, and also through the Indonesian Student Sports Development Board (BAPOMI). From the first in 1990 in Yogyakarta until the XV in Makassar in 2017, POMNAS has contributed a lot of athletes to represent Indonesia at the international level. POMNAS is very important because its sport branches are related to Olympic sports, such as athletics and aquatics.

The sport branches that are competed and contested at POMNAS refer to the 2013 POMNAS regulation article 7 . The regulation states that the sports that are competed and contested consist of mandatory and other sports, which are obligatory, namely: athletics, swimming, and others, namely; 1) games or games: volleyball, futsal, football, table tennis, basketball, hockey, softball, and sepak takraw (choose 4 branches); 2) martial arts: pencak silat, taekwondo, karate, judo, wrestling, wushu and kempo (choose 3 branches); 3) rackets: badminton, tennis, and squash (choose 2 branches); 4) concentration: archery, chess, bowling, bridge and rock climbing (choose 2 branches). 5) other branches according to the needs and or agreement of the organizer.

North Maluku's participation has not been satisfactory, but there has been improvement in the last two POMNAS. North Maluku only managed to get a bronze medal in the pencak silat branch at POMNAS Aceh in 2015 and 4 (four) bronze medals in the petanque branch at POMNAS Makassar in 2017.

Despite the improvement of North Maluku in POMNAS, it is not passable. This achievement is expected to be better in POMNAS 2019 and also in POMNAS in the future. To maintain and improve achievement, it takes hard work and optimizes the process, which includes the athlete selection process, competition tests, funding, and athlete nutrition. The process towards greater achievement requires readiness, both mentally and physically. The mental factor of the athlete is very important to note. However, its implementation is still very lacking, following what was experienced by the North Maluku BAPOMI management. Through an interview on 27 March 2019, the North Maluku BAPOMI administrator Mr. Mukhlis Nur Ohoirat A. Gani, stated that until now there is still a lack of implementation.

Based on the results of the interview above, there is a research linkage to the mental factors of athletes, revealing that the demands for achievement are sometimes felt heavy by athletes, pressure in the form of verbal violence during training is often experienced by athletes so that athletes are frustrated (Kavanagh et al., 2017). In addition to verbal violence during training, in different contexts, demands for academic quality also affect, because the athletes are students, the results of the study indicate that there is a decline in academics in college athletes (Gomez et al., 2018). According to (Douglas \& Carless, 2010), it is stated that an athlete whose mental breakdown during competition leads to wasted training. The mental breakdown of 
athletes according to research by (Aarresola et al., 2017), is caused by 1) institutionalnormative experiences related to rationalized sports systems, 2) personal development experiences related to skills learning and personal recognition, shaping lifestyles and overcoming difficulties, 3 ) experience social capital is built through family, friends, and coaches, and use of resources in competitive sports, 4) unforeseen life events consist of injuries, illnesses, and various social life events, such as the death of a family member.

The dynamics above are in line with the research finding by (Zuber \& Conzelmann, 2014), it described the importance of the athlete's mentality, such as achievement motivation which is positively correlated with athletes' efforts, although several other factors hinder achievement, such as fear of failure, and hope to succeed. Achievement motivation has a very important role, this is based on research that shows that achievement motivation has a role of $41.6 \%$ in badminton athletes (Hannah \& Wulandari, 2014) and athlete anxiety (Hardiyono, 2020), so achievement motivation must be owned by athletes. Every athlete as well as the North Maluku contingent POMNAS athletes. Motivational factors, a survey was done by (Kuspriyani \& Setyawati, 2014), influenced by the indicator of personality factors was $78 \%$, the influence of the situation $92 \%$, yield trend factor $89 \%$, emotional reaction factor $84 \%$, and the behavioral factor of achievement is $86 \%$ in the badminton athletes of the Pendowo Semarang club. Furthermore, self-efficacy helps predict a person's motivation and performance. According to Jarvis
(Weinberg \& Gould, 2015), self-efficacy is the athlete's feeling about himself. The results of research on physical education students show that self-efficacy is positively correlated with emotional intelligence and is also the best predictor of self-efficacy levels (Adilogullari \& Senel, 2014).

Self-efficacy based on (Wade \& Tavris, 2012) is an individual's belief that he is capable of doing something. If an athlete believes that he can win in a competition, then that possibility of winning increases. The research found the factors that affect self-efficacy namely, the best experience, a sense of familiarity, and experience overcoming difficulties and facing challenges (Anstiss et al., 2018). In addition, (Stander et al., 2015) stated that teammates and self-efficacy are established as the best predictors of the athlete's experience. Self-efficacy is correlated with sustained exercise (LaForge-MacKenzie \& Sullivan, 2014).

As it been mentioned before, it is important to examine the psychological dynamics of athletes comprehensively, namely how an athlete must be able to know and manage the mental itself, such as achievement motivation, self-efficacy, selfconfidence, and self-esteem. Nevertheless, various research results that discuss the factors of physical condition, nutrition, anatomy, physiology, biomechanics, and also from various other disciplines only support sports achievement. The problems described above illustrate that the psychological dynamics of an athlete are so complex to be discussed one by one. Therefore, there is a need for a more detailed special discussion to reveal the 
gaps in athletes. It can be said that an athlete who has followed, doing various training programs will be useless if the athlete's mentality is not good. An athlete will make fewer mistakes or make no mistakes at all if the supporting factors in the achievement progress are appropriate. Thus, through this study researchers will examine and analyze in-depth related to the self-efficacy of North Maluku athletes at the National Student Sports Week.

\section{METHODS}

This study uses a qualitative approach. This research was carried out at BAPOMI, North Maluku, and happened in April 2019. The qualitative method is a method that produces descriptive data in the form of written or spoken words from people and observed behavior.

Data collection is important because if an error occurs in the data processing, the wrong conclusion will be obtained. Data collection relates to the selection of appropriate data collection techniques and tools.

\section{Participants}

The objects of this study are North Maluku athlete students' self-efficacy at POMNAS 2019 that held in Jakarta.

\section{Design or Data Analysis}

The stages that are passed before holding an interview are the selection of individuals who will be interviewed. In this case, the selection of informants who are considered capable of providing answers to the questions raised about the problem under study is carried out.
Observation is the main method to get information where researchers observing behavior in a state of nature, observing dynamics, observing a picture of behavior based on the existing situation.

Documentation is the collection of data through written remains in the form of archives, books, and newspapers as evidence showing events or activities related to this research.

\section{RESULT}

North Maluku athlete student self-efficacy

Self-efficacy is a feeling of confidence that athletes have in their ability to complete specific tasks or self-confidence to be able to carry out a series of activities to produce something. An athlete needs to know his ability to complete the stages and stages of each training program. Specifically, selfefficacy in this study is the self-efficacy of North Maluku athlete students in carrying out tasks as athletes which include training efficacy and competitive efficacy. The athlete's self-efficacy in the analysis of this stage will reveal the phenomenon of selfefficacy of North Maluku athlete students expressed through three aspects, the first is the magnitude aspect, the second is a generality, and the third is strength. Referring to the formulation of the problem in this study, namely what forms the selfefficacy of North Maluku athlete students. Therefore, the results of the analysis of this study will focus on three aspects to reveal what will support these three aspects in increasing the self-efficacy of North Maluku athlete students. 
Magnitude Aspects of North Maluku Athlete Students

The burden of training for an athlete is not something new, the severity of training is often a scourge for athletes. Undergoing training with a specific purpose is an integral part of the training material that athletes must undergo. Athletes who have high self-efficacy will feel confident about their abilities which refers to the level of the training material. The findings of this study have provided an overview of the level of exercise perceived by athletes. Athletes have felt the weight of the training material they undergo every time they face an event. The weight and lightness of the training material undertaken by athletes will shape their physical abilities and provide additional insight into the athlete's capacity to face opponents in matches.

Magnitude/level in the training material is very dependent on the physical condition of the athlete because to avoid excessive training loads or not in line with the athlete's physical condition, the athlete will become injured. In this study, researchers found that athletes were well aware of the training load they were undergoing and also realized their capacity to complete the training material. Based on the results of the interview on 18/08/2020 with interviewee 1 as follows:

"Yes sir, I have started to feel the weight of the training load, but I am not burdened by the weight of the exercise".

The excerpt from the interview above provides an overview of the findings of this study. The expression above clearly explains that athletes are well aware of the burden of the training material they are undergoing.
But on the other hand, athletes are also not burdened with the weight of training. It illustrates that, athletes know their capacity to complete the entire set of training materials provided by the coach. Heavy training load is the most common instrument when the physical response is given a load, and the instrument is also to measure the individual's capacity to face the opponent. It is closely related to the physical condition of the athlete himself, meaning that an athlete must maintain his physical condition so that he is always fit. All activities that can damage the immune system should be avoided, such as smoking, staying up late and or doing activities that cause physical injury. It is not easy or not to be influenced by activities that harm oneself in carrying out the profession as an athlete. The interview results above are supported by the results of the interview with Resource Person 2 on 20/08/2020, and also the results of the interview with Resource Person 3 on 29/08/2020.

Generality Aspect of North Maluku Athlete Students

Characteristics of athletes who have high self-efficacy are having generality or broad behavioral space. Generality is the extent to which athletes believe in their abilities in various training or competing situations, ranging from doing an exercise activity or a certain situation to a series of exercises or situations that vary. Generality in this study is expressed through, first, namely; the feeling of being able to overcome various difficulties in dealing with opponents, and the second is; Defeat an opponent who feels capable of being defeated to avoid defeat. Referring to the 
results of this study, the researcher revealed that winning in a competition was not always a priority, but the most important thing was breaking personal records. Here are excerpts from his interview:

"If you compete yesterday to improve your limit, if you beat your opponent, it's not too prominent, if you don't win, the important thing is to break your record. So, if the results of the competition decrease, it becomes a burden on your mind" (interview on 28/08/2020).

Generality is one aspect that must be owned by athletes to measure the level of self-efficacy. Athletes will perform a series of exercises in which the training material obtained from the trainer varies. Here the athlete certainly performs various tasks or training activities at once with a variety of exercises. So, athletes who have high selfefficacy will carry out a series of exercise programs. To reveal the generality in this study, the following are the results of interviews with athletes.

"I always believe I can beat my opponent, because I believe in the training I have been through" (interview on $18 / 08 / 2020$ ).

Based on the results of the interviews above, the researchers found that athletes have a good view of the generality (wide area of behavior) of athletes. It means that athletes are position conscious, so athletes who have high self-efficacy can be seen from their belief in a series of training programs that have been undertaken.
Strength Aspect of North Maluku Athlete Students

In the aspect of strength, it is the degree of the athlete's ability to his beliefs or expectations. Thus, an athlete with weak self-efficacy will easily succumb to unsupportive experiences. Meanwhile, an athlete with high self-efficacy will encourage himself to stay in his business even though experiences are found that do not support or hinder. Characteristics of high self-efficacy possessed by athletes are having a high level of strength, which is seen from athletes having a level of strength from beliefs about their abilities.

Athletes who have undergone a long training process, then have undergone various competitions, will certainly provide more compensation, therefore, the form of strength is that the experience gained has given a strength that indirectly fosters confidence in their ability to beat their opponents in a match. . The following are excerpts from research results through interviews with athletes;

"I feel that if I have practiced well, then I am confident in my abilities" (interview on 18/08/2020).

Self-efficacy in this finding is a characteristic of athletes who have high selfefficacy, because athletes who have low self-efficacy, then these athletes do not have the strength (steadiness of belief) in what they have obtained. Although athletes have undergone a long training process, then have completed various pilot programs, but if there is any doubt during a match, then the possibility of losing is very large. Therefore, the principles of practicing regularly will 
form the strength (steadiness of belief) of athletes.

\section{DISCUSSION}

Efficacy is a feeling of confidence that athletes have in their ability to complete specific tasks or self-confidence to carry out a series of activities to produce something (Wade \& Tavris, 2012). An athlete needs to know his ability to complete the stages and stages of each training program.

Self-efficacy discussed in this study is the self-efficacy of North Maluku athlete students in carrying out tasks as athletes include training efficacy and competitive efficacy. This study will reveal the phenomenon of North Maluku athlete students' self-efficacy expressed through three aspects based on (Weinberg \& Gould, 2015) those are, the magnitude aspect, the generality aspect, and the strength aspect. Referring to the problem formulation in this study that is what determine the self-efficacy of North Maluku athlete students at POMNAS DKI Jakarta.

The research results from (Van Raalte \& Posteher, 2019) have also discussed the students' self-efficacy problem. In the magnitude aspect, athletes have felt the weight of the training load. In the generality aspect, athletes become convinced that specific exercises will support them in achieving. Meanwhile, in the strength aspect, athletes believe in their abilities to get achievement, even though various obstacles come in their way.

\section{CONCLUSION}

1) Researchers found that athletes who have high self-efficacy are athletes who know the level of a series of training programs

2) Researchers found that athletes who have high self-efficacy are athletes who know their abilities in undergoing a series of training programs

3) Researchers also found that athletes who have high self-efficacy are athletes who have strength in undergoing a series of training programs, this is indicated by the athlete's ability to complete the entire set of exercises.

\section{REFERENCES}

Aarresola, O., Itkonen, H., \& Laine, K. (2017). Young Athletes' Significant Experiences in Sport: Critical Sociological Reflections on Athlete Development. European Journal for Sport and Society, 14(3), 265285.

https://doi.org/10.1080/16138171.2017.13 49067

Adilogullari, I., \& Senel, E. (2014). Examination of the Relationship Between General Selfefficacy Beliefs, Emotional Intelligence Levels and Emotional Self-efficacy Levels of Students in School of Physical Education and Sport. The Anthropologist, 18(3), 893-902. https://doi.org/10.1080/09720073.2014.11 891621

Anstiss, P. A., Meijen, C., \& Marcora, S. M. (2018). The Sources of Self-efficacy in Experienced and Competitive Endurance Athletes. International Journal of Sport and Exercise Psychology, 1-17. https://doi.org/10.1080/1612197X.2018.1 549584

Douglas, K., \& Carless, D. (2010). Restoring Connections in Physical Activity and Mental Health Research and Practice: A Confessional Tale. Qualitative Research in Sport and Exercise, 2(3), 336-353. 
https://doi.org/10.1080/19398441.2010.51 7039

Gomez, J., Bradley, J., \& Conway, P. (2018). The Challenges of a High-Performance Student Athlete. Irish Educational Studies, 37(3), 329-349. https://doi.org/10.1080/03323315.2018.14 84299

Hannah, Y. P., \& Wulandari, D. A. (2014). Hubungan Antara Motivasi Berprestasi Dengan Burnout Pada Atlet Bulutangkis Di Purwokerto. Psycho Idea, 12(1), 10-18. https://doi.org/10.30595/psychoidea.v12i1 .517

Hardiyono, B. (2020). Tingkat Kecemasan Sebelum Bertanding Dan Percaya Diri Pada Saat Bertanding Atlet Pelatda Pengprov FPTI Sumatera Selatan. Kinestetik, 4(1), 47-54. https://doi.org/10.33369/jk.v4i1.10399

Kavanagh, E., Brown, L., \& Jones, I. (2017). Elite Athletes' Experience of Coping With Emotional Abuse in the Coach-Athlete Relationship. Journal of Applied Sport Psychology, 29(4), 402-417. https://doi.org/10.1080/10413200.2017.12 98165

Kuspriyani, D. S., \& Setyawati, H. (2014). Survei Motivasi Prestasi Atlet Klub Bulutangkis Pendowo Semarang Tahun 2014. Journal of Physical Education, Health and Sport, 1(2), 108-114. https://journal.unnes.ac.id/nju/index.php/j pehs/article/download/3209/3183

LaForge-MacKenzie, K., \& Sullivan, P. J. (2014). A Comparison of the Self-efficacyPerformance Relationship Between Continuous and Noncontinuous Sport Conditions. Journal of Applied Sport Psychology, 26(3), 363-376. https://doi.org/10.1080/10413200.2014.89 4154

Stander, F. W., Rothmann, S., \& Botha, E. (2015). The Role of Teammate Relationships, Communication and Selfefficacy in Predicting Athlete Flow Experience. Journal of Psychology in Africa, 25(6), 494-503. https://doi.org/10.1080/14330237.2015.11 24600

Van Raalte, L. J., \& Posteher, K. A. (2019).
Examining Social Support, Self-Efficacy, Stress, and Performance, in U.S. Division I Dollegiate Student-Athletes' Academic and Athletic Lives. Journal for the Study of Sports and Athletes in Education, 13(2), 75-96.

https://doi.org/10.1080/19357397.2019.16 35419

Wade, C., \& Tavris, C. (2012). Invitation to Psychology (5th ed.). Prentice Hall.

Weinberg, R. S., \& Gould, D. (2015). Foundations of Sport and Exercise Psychology (Human Kinetics (ed.); 6th ed.).

Zuber, C., \& Conzelmann, A. (2014). The Impact of the Achievement Motive on Athletic Performance in Adolescent Football Players. European Journal of Sport Science, 14(5), 475-483. https://doi.org/10.1080/17461391.2013.83 7513 